\title{
Implementation of Estrus Synchronization and Artificial Insemination Program (GBIB) in West Waringin Kota District, Central Kalimantan Province of Indonesia
}

\author{
Tresia Kristiana ${ }^{1 *}$ and Harapin Hafid ${ }^{2}$ \\ ${ }^{1}$ Program Study of Government Science, Faculty of Social and Political Sciences, Kristen University ${ }^{2}$ Palangka Raya, Central \\ Kalimantan, Indonesia \\ ${ }^{2}$ Program Study of Animal Science, Faculty of Animal Science, University of Halu Oleo Kendari South East Sulawesi, Indonesia
}

\begin{abstract}
The government has launched a program of self-sufficiency in meat as an effort to overcome the shortage of beef supply to meet the needs of the community, especially when the day of religious festivities. GBIB program Implementation is expected to meet the needs of the community will be beef, as demand for beef is always soaring demand every year, especially ahead of religious festivals. To discuss and review the implementation of the program stretcher author uses the theory EDWARDS III to determine the success or failure of the implementation of the program in the district of Kota Waringin Barat. Issues to be examined are 1) the quality and quantity of resources, 2) communication and dissemination program, 3) Attitude 4) Bureaucracy. This will be the focus to see the successful implementation of the program of snapping / sync Lust and optimize of GBIB in the district of Kota Waringin. This study uses the concept of a qualitative descriptive approach with the aim of providing an overview of how the implementation of the field program and then analyzed using the theory of Edwards III. The results of this study show that: 1) Aspects of Resource (HR, Information, Privileges and amenities), some support as the support means the production of drugs / vitamins and breeding stock (straw) superior adequate and well as the authority and the information available is quite good, while some aspects that do not support such as: HR, execution time, geographical conditions, transport facilities support, 2) aspect Communications (Transmission, Clarity, Consistency and Coordination) strongly supports the implementation of the program GBIB is 3) aspects of attitude (attitude implementer, Support Leader, Incentives for implementing and Transparency), relatively supportive in this program, and 4) Structural Aspects of Bureaucracy (SOP and Fragmentation) still do not support the implementation of the Program snapping Sexual arousal and this Artificial Insemination.
\end{abstract}

\section{Introduction}

General policy of agricultural development is to create added value and competitiveness of agriculture by enhancing the role and participation of the agricultural community and the implementation of good organizational management based on the application of science and technology. Of public policy are translated into a technical policy where implementation is organized on the principle of economic unity, so that all elements of the powers that be in synergy with one another.

Law No. 7 of 1996 concerning food security, the fulfillment of food for households which is reflected in the availability of adequate food, both in number and quality, safe, equitable and affordable. Food security can be simplified by focusing on three dimensions of different but interrelated namely food availability (production), access to food by households (distribution), and utilization of food by individuals (consumption).
The situation of national consumption of animal food is still dominated by a relatively high consumption of meat, where meat is a basic requirement of the most important and is considered by the government, either the stock / reserves and its market price. Then to secure food situation should be supported by the population of livestock enough, one of the steps taken by the government, namely the implementation of artificial insemination programs in order to stimulate the birth rate of cattle in order to meet the food needs of the community.

Directorate General of Livestock and Animal Health is a government agency that has the task of formulating and implementing policies and technical standardization in the field of animal husbandry and animal health functions include breeding, feed, livestock farming, animal health and veterinary public health. Challenges in implementing the tasks and functions is not easy in the midst of challenges faced include:

(1) The population growth and the increasing need of the productive age group of animal-based food supply that is 
safe, healthy, whole and kosher (FOSTER) becomes larger;

(2) The transformation of the use of agricultural land to non-agricultural become a limiting factor in increasing production and productivity of the agricultural sector, including livestock;

(3) Competition not only for the use of food commodities (food), feed (feed) and energy (fuel), for example maize;

(4) Sentra producer and consumer centers are located far apart in need of transportation facilities and adequate logistics ;

(5) Synchronization central policy areas as the impact of regional autonomy;

(6) The liberalization of world trade pose a threat of imported products; and

(7) The global climate change.

In the midst of the challenges faced, the Directorate General of Livestock and Animal Health has been and will carry out various activities in order to support the duties and functions of which are: Development of Livestock Breeding, Aquaculture Development Cattle Artificial Insemination (AI). In an effort to increase the population and productivity of cattle and buffaloes that lead to self-sufficiency in beef and buffalo.

Government through the Directorate General of Livestock and Animal Health Ministry of Agriculture in 2015 launched a program through bullying Lust Optimization Birth of Artificial Insemination (GBIB). Kalimantan Tengah into one of the working area of the program with technical companion Livestock Breeding Center for Excellence (BPTU) Pleihari as Technical Implementation Unit (UPT) of the Directorate General of Livestock and Animal Health. Benefits of Artificial Insemination efficiency is more time, where to marry the cattle ranchers no longer need to look for bulls (bull), simply contact inseminator breeders in their area and determine the desired seed.

Acceleration of Population Increased activity by snapping Lust and Artificial Insemination (GBIB) in Central Kalimantan Province Regional TA.2015 will be made with a target of 5000 for snapping tail oestrus in 14 Districts / Municipalities. For West Kotawaringin target for GBIB many as 800 animals or $16 \%$ of the target provinces, (Evaluation Report Activity deploy GBIB, BPTU-HMT Pelaihari, 2015)

Sexual arousal bullying programs and Insminasi Artificial (GBIB) is a program for increasing the population increase through estrus synchronization and optimization of Artificial Inseminisasi. GBIB program which is one of the government programs in order to fulfill the needs of meat adequacy society. Sexual arousal bullying program and Artificial Insemination (GBIB) very well be applied in order to help farmers / ranchers in an attempt to create a pregnancy cows simultaneously. GBIB is one right way to further increase the lust of cows and buffaloes to ease the process of mating. That way, potential pregnancy cows to be faster to produce new offspring.

At first in Kotawaringin Barat livestock population improvement program carried out through a process of natural mating. Animal mating process is done by cows are married males / natural. However, it is felt less than optimal because it was feared happened inbreeding (inbreeding), so the program is necessary to prevent GBIB descended from the male parent and incest (in breeding) because it can produce offspring that are less good his performance.

Artificial Insemination Program (IB) alone in West Kotawaringin have dilaksanan since the period of 1990 but lack of government financial support. Artificial Insemination (AI) has aggressively implemented around the period of 2010 until now. The problems studied were: 1) How to program implementation snapping Sexual arousal and Artificial Insemination (GBIB) in Kalimantan Tengah Kotawaringin Barat?. 2) How is the target and the realization of snapping Sexual arousal and Artificial Insemination (GBIB) in Kotawaringin Barat Provinsi Kalimantan Tengah Indonesia?. The benefits of this research are expected to provide feedback / input to the Regional Government of Kota waringin Barat especially Agriculture and Livestock Kota waringin Barat towards the implementation of the Program snapping Sexual arousal and Artificial Insemination and can make a positive contribution in order to achieve food needs in Kotawaringin Barat and follow-up of GBIB program in the future.

\section{Methodology}

This study used a qualitative approach, where data shown generally shaped descriptions and sentences is a description of the factual and accurate, as well as the relationships among the issues examined in a qualitative approach, the researchers went to the field to examine the object of its studies and hold a direct interaction with society aims to get in-depth information about the professionalism including obstacles faced and the efforts made to overcome them. This is based on qualitative research purposes to generate descriptive data in the form of words written or spoken of people and behaviours that can be observed [5].

The data collection is done by observation, interview (Interview) and documentation. The analysis began to formulate and explain the problem, before plunging into the field, and continue until the writing of the research results. The data have been collected later clarified to be analyzed using inductive analysis approach. Furthermore, using data analysis developed by Miles and Huberman, with three types of activities, namely; data reduction, data presentation, and conclusion / verification.

\section{Research Result}

The number of cattle population in Kalimantan Tengah is still far from sufficient to meet the needs of people of Kalimantan Tengah meat. Overview cattle population in Kalimantan Tengah can be seen from Table 1 below. 
Table 1. Cattle Population development and buffalo. Fixed

figures (ATAP) in 2015 and a Preliminary figures (ASEM) in 2016 in the province of Central Kalimantan.

\begin{tabular}{|c|c|c|c|c|c|c|c|}
\hline $\begin{array}{l}\text { No } \\
\text { ATAP 2015 } \\
\text { ASEM } 2015\end{array}$ & $\begin{array}{l}\text { Kabupaten/ Kota } \\
\text { Jumlah 2015 Populasi } \\
\text { Jumlah 2016 }\end{array}$ & Populasi & & & & & \\
\hline 1 & $\begin{array}{c}\text { Sapi } \\
\text { Kotaxaringin Barat }\end{array}$ & $\begin{array}{l}\text { Kerbay } \\
14.397\end{array}$ & 0 & $\begin{array}{l}\text { Sapi } \\
14.397\end{array}$ & $\begin{array}{r}\text { Kerbau } \\
16.933\end{array}$ & 0 & 16.933 \\
\hline 2 & Kotawaringin Timur. & 6.948 & 192 & 7.140 & 7.203 & 211 & 7.414 \\
\hline 3 & Kapuas $\quad 3.076$ & 14 & 3.090 & 3.200 & & 3.220 & \\
\hline 4 & Barito Selatanl .125 & 9.773 & 10.898 & 1.150 & 10.202 & 11.352 & \\
\hline 5 & Barito Utara 3.080 & 135 & 3.215 & 3.125 & 146 & 3.271 & \\
\hline 6 & Sukamara 2.794 & 0 & 2.794 & 2.934 & 0 & 2.923 & \\
\hline 7 & Lamanday 3.816 & 0 & 3.816 & 3.925 & 0 & 3.925 & \\
\hline$\$$ & Seruxan $\quad 7.767$ & 6 & 7.773 & 8.155 & 0 & 8.155 & \\
\hline 9 & Kating pan. & 331 & 8.225 & 8.829 & 368 & 8.657 & \\
\hline 10 & Pulang Pisau 8.825 & 15 & 8.840 & 9.293 & 15 & 9.308 & \\
\hline 11 & Gunung Mtas 4.034 & 141 & 4.175 & 4.100 & 150 & 4.250 & \\
\hline 12 & Barito Timur 1.261 & 789 & 2.050 & 1.324 & 1.093 & 2.417 & \\
\hline 13 & Murung Raya & 1.721 & 8 & 1.729 & 1.763 & 10 & 1.773 \\
\hline 14 & Kota Palangla Raya & 1.793 & 13 & 1.806 & 1.999 & 15 & 2.014 \\
\hline & Kalteng $\quad 68.531$ & 11.417 & 79.948 & 73.393 & 12.230 & 85.623 & \\
\hline
\end{tabular}

Kota Waringin Barat is the region with the highest number of cattle population throughout Kalimantan Tengah. But the production and productivity of livestock still cannot meet local demand. Various efforts and programs have been undertaken to stimulate the growth of birth rate among other Cows Integration Oil, Utilization ex. mine for cattle, cows integration with agricultural crops and Artificial Insemination program / GBIB, [13].

Program snapping Sexual arousal and Artificial Insemination (GBIB) initiated by the central government through the Ministry of Agriculture in this case the Directorate General of Livestock and Animal Health intends to accelerate the increase in population through a snapping / synchronization of oestrus and optimization of Artificial Insemination (GBIB) as well as the prevention of reproductive disorders in cattle / buffalo. Sexual arousal bullying program and Artificial Insemination (GBIB) aims to: 1) Optimizing the implementation of the IB; 2). lust in an effort to accelerate the birth; 3). Increased acceptor IB; 4). expand the range of services IB; 5). Settlement of the case of reproductive disorders 6) establishment of livestock, especially cattle population increase in the target areas of activity, 7) ensuring adequate support in the provision of livestock in the framework of the national meat selfsufficiency and 4) increasing prosperity and income of farmers / ranchers with additional births superior cattle. To support the implementation of the program GBIB necessary target data as in the Table 2 .

Table 2. Program targets bullying Sexual arousal and Artificial Insemination by decree of the Head of Agriculture and Livestock of Central Kalimantan Number: 313 / Kpts / Nak-400 / IV / 2015 dated April 16, 2015.

\begin{tabular}{|c|c|c|c|c|c|c|c|c|}
\hline \multirow{3}{*}{$\begin{array}{l}\text { No } \\
1 \\
2\end{array}$} & \multirow{2}{*}{\multicolumn{2}{|c|}{ 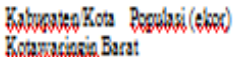 }} & \multicolumn{2}{|c|}{ 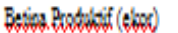 } & \multicolumn{2}{|c|}{ 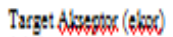 } & \multirow{7}{*}{ 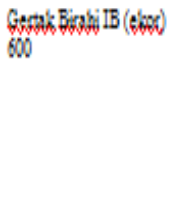 } & \multirow{16}{*}{ 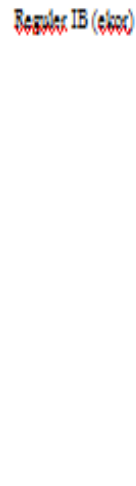 } \\
\hline & & & 12544 & 6.193 & 4.440 & 8000 & & \\
\hline & Burm Uan & 2992 & 1.199 & 1000 & 300 & 300 & & \\
\hline 3 & Rapass & 3.638 & 94? & 900 & 400 & 380 & & \\
\hline 4 & 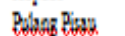 & 8330 & 4500 & 3.400 & 1000 & 700 & & \\
\hline 3 & Burs Stiana & 868 & 363 & 203 & 30 & 25 & & \\
\hline 6 & B & 8081 & 2029 & 1.780 & 780 & 300 & & \\
\hline$?$ & Botoming $\mathrm{T}$ & $m$ & 6872 & 2787 & 2000 & 730 & 8000 & \\
\hline 8 & phoofla $\mathrm{R}_{y}$ & 1725 & 842 & 380 & 200 & 1000 & & \\
\hline 9 & shamg. & 2687 & 1901 & 300 & 100 & 230 & & \\
\hline 10 & Strowa & 7314 & 3.400 & 1500 & 400 & 100 & & \\
\hline II & Hom & 2917 & 817 & 700 & 200 & 600 & & \\
\hline$\ddot{i}$ & $G=0, b^{1}$ & 3.965 & 980 & 380 & 130 & 150 & & \\
\hline 13 & 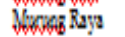 & 1.039 & 411 & 330 & 100 & 200 & & \\
\hline & Busto $T$ max & 1.787 & 899 & 380 & 200 & 300 & & \\
\hline ming & 64.046 & 27.17 & $17 m 3$ & 3.700 & 3328 & & & \\
\hline
\end{tabular}

From the above table it is known that out of the fourteen districts in the Province of Kalimantan Tengah, Kota waringin Barat received an allocation of snapping Lust IB 800 and IB Regular tail 600 tail. The allocation is distributed according to ability and absorption area per district. Six districts targeted GBIB program is Kumai, South Arut, North Arut, Pepper Base, Base Bull, and
Kota waringin. Regular IB Program is a program implemented regularly served by the clerk inseminator throughout the year ranging from the beginning of the year until the end of the year.

Sexual arousal snarled IB GBIB done for their program. GBIB program for 2015 has just been implemented planning beginning of September 2015 
until the end of 2015 (4 months). GBIB program allocated to target farmers who are not served by regular IB activities. GBIB Program Results can be seen in the following Table 3.

Table 3. The realization results of implementation activities GBIB 2015 in Kalimantan.

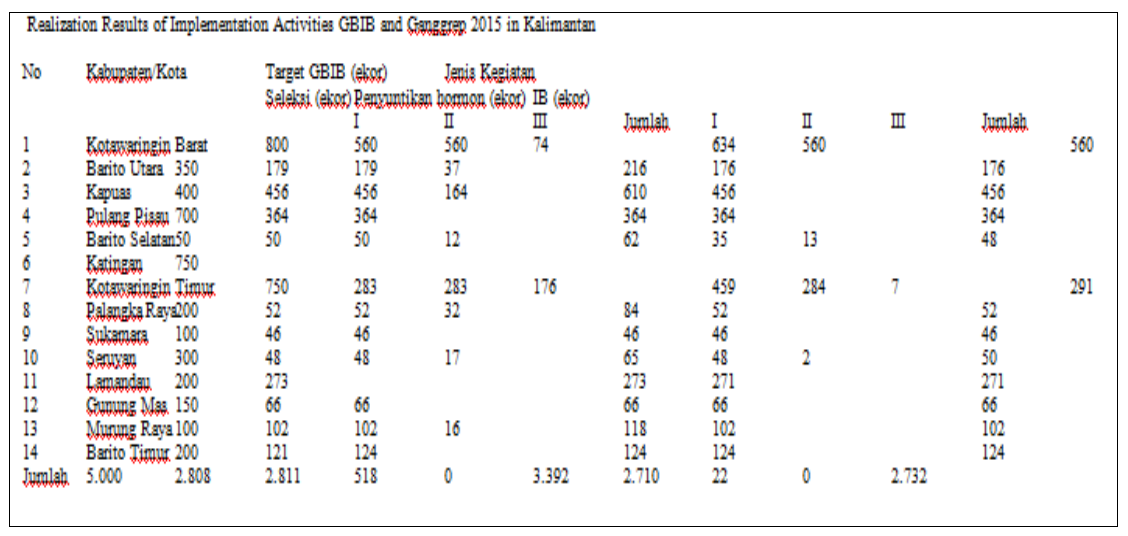

GBIB target achievement in West Kotawaringin highest throughout Kalimantan Tengah although it cannot reach $100 \%$ of the specified target. GBIB of the province are set to Kota waringin Barat is 800 breeding. Target achievement during the period of 4 (four) months produce a pregnancy rate of 560 head or about $80 \%$. If the program is implemented for a period of 1 (one) year results will be three times that of the achievements of current or tail $560 \times 3=1680$ tail pregnancy. If the tail is calculated from 1680, mean performance target of 800 animals of about $200 \%$. So if the government program was implemented at the beginning of the year until the end of the outcomes are 1.680 tail mean exceeded the target set at 800 animals.

Economically if in view the realization of the achievement of the program as much as 560 tails GBIB calf's birth, if the selling price is calculated derivative / calf superior to average around Rp. 6,000,000 / tail then the impact of the economic value created from GBIB program in the community is about 560 tails X Rp. $6,000,000=$ Rp. 3.36 billion (three billion three hundred and sixty million). Comparing the results of IB derivatives with natural mating process, the selling price higher derivatives IB results because of a genetic child produced superior results than children. The average difference obtained difference Rp.2.000.000 field, - s / d $2.500 .000,-/$ tail, higher selling prices calf IB results.

Sexual arousal bullying program and Artificial Insemination (GBIB) through decision of the Directorate General of Animal Husbandry and Health No. 209 / KPTS / OT.160 / F / 03/2015 ON Steering And Implementing Activity Team to Accelerate Improved snapping population through Birahi And Optimization of Artificial Insemination (GBIB) 2015 revised budget funds are expected to increase the population of hearts Frame Capable of supporting an increase in the Regional Food Security. In the West Kotawaringin, cultivation Cattle Enough Operating long cultivated traditional, Livestock Just released dikebun or dilahan and NOT require expensive Investment and labor, while cattle require intensive maintenance Patterns a More Attention from peternaknya. Thus requiring additional cost between others includes power for feed, cages Management and Others.

- $\quad$ Analysis Model Program by Edwards III

The benefits of a program will be felt if the program can be implemented properly. Implementation of a program is a dynamic process that includes the interaction of many factors.

- $\quad$ Theoretically, according to Edwards III

There are four variables that influence the implementation of the program, namely communication, resources, attitudes and bureaucratic structure.

\subsection{Communications (Communications)}

According to Edwards III, there are three important things that can be discussed in the communication process program, namely the transmission, clarity (clarity) and consistency.

\subsubsection{Transmission}

In connection with the Program snapping Birahi Artificial Insemination (GBIB) in West Kota waringin and based on interviews with the Head of Development of Livestock Production Department of Agriculture and Animal Husbandry West Kota waringin note that the implementation of the program in West Kota waringin already know and understand what to do in connection with the implementation Sexual arousal snarled Artificial Insemination program (GBIB) this.

\subsubsection{Clarity (Clarity)}

Clarity of information about the aims and objectives snapping lust artificial insemination (GBIB), based on the observation of rules and regulations regarding the implementation of this program has been described in detail through the General Guidelines for the 
Implementation of bullying Sexual arousal and Artificial Insemination (GBIB), Technical Guidelines Program snapping Sexual arousal and Insemination artificial (GBIB) as well as the decision of the Directorate General of Animal Husbandry and Health No. 209 / KPTS / OT.160 / F / 03/2015 on the Steering Committee and Project Implementation Acceleration Population Increased by snapping Sexual arousal and Optimization of artificial Insemination (GBIB) 2015 revised budget funds. Agriculture and Livestock of Central Kalimantan Province, Permentan, GBIB General Guidelines and Technical Guidance has been submitted to the Department of Agriculture and Livestock

Support Regulations / Legal Foundation Recipient Regulation

1. General Guidelines for the Implementation of bullying Sexual arousal and Optimization of Artificial Insemination (GBIB) 2015

2. Technical Guide Budget Management Tasks Directorate General of Livestock and Animal Health had been

3. Technical Guidelines snapping Activity Sexual arousal and Optimization of Artificial Insemination (GBIB) 2015

4. Already decision of the Directorate General of Animal Husbandry and Health No. 209 / KPTS / OT.160 / F / 03/2015 on the Steering Committee and Project Implementation Acceleration Population Increased by snapping Sexual arousal and Optimization of Artificial Insemination (GBIB) funds APBNP 2015

Source: Dinas Pertanian dan Pertenakan Kabupaten Kota Waringin Barat.

\subsection{Resource}

\subsubsection{Human Resources}

The resources in the implementation of programs in the district of Kota Waringin GBIB West still less support is the Human Resources (HR) in the Livestock Production Development Division amounted to 15 (fifteen) people and has included Head of Division and Head of Section. There should be additional staff, especially staff parts of the field as Agricultural Extension Officers (PPL). For inseminator officers have formed an independent and spontaneous inseminator no division but due to spontaneous inseminator officer status, so as to coordinate official considerably less flexible. PPL's position is under the Office of Agricultural Extension and Food Security, when PPL entered into the Organization Department of Agriculture and Animal Husbandry then expected to add more strength to the Department of Agriculture and Animal Husbandry field.

\subsubsection{Facilities}

Facilities provided include the provision of seeds / straw superior cows of different races / nations veal obtained from the national superior male sperm to adjust to the circumstances and demands of the farmers on the location of activities. It is absolutely necessary given the circumstances and the situation of livestock breeders who are expecting are married injection / IB with superior seedlings. The facilities provided in the form of the hormone prostaglandin 2 alpha, for the implementation of estrus synchronization in order to obtain some cows were estrus IB simultaneously and in unison. Provision of Medicines and vitamins are the initial stimulus for farmers who have become acceptors GBIB and applications performed by veterinariansadan paramedic's trained animal health.

\subsubsection{Attitude}

The attitude of the public in this case farmers strongly supports the program GBIB, seen from the success made by the inseminator which has been designated by the Department of Agriculture and Animal Husbandry Kota waringin Barat, although implementation in just four (4) months showed a pretty good result, 800 tail which is targeted to achieve the realization of as many as 560 cows pregnant. The involvement of various parties, especially from the Agriculture and Livestock Kota waringin Barat show a good attitude in the implementation of bullying / lust Insemination (GBIB).

\subsubsection{The bureaucratic structure}

Bureaucratic structure which is owned not enough to support the implementation of the Program snapping Sexual arousal and Artificial Insemination (GBIB) is in terms of the SOP and fragmentation factor. In the conduct of the Program snapping Sexual arousal and Artificial Insemination (GBIB) The SOP and the section that deals specifically with this program yet, which resulted in the duties and authorities of each section is less clear and this program is less able to run with the maximum because the workload is greater submitted the Head of Development of Livestock Production.

\section{Conclusion}

1. Implementation Program GBIB implemented in the district of West Kota Waringin has been executed, communication goes well, sosialisasi implemented so understanding of the technical and operational guidelines to understand the program's implementation GBIB inseminator who have by the Agriculture and Livestock District Municipality, Resources limited human does not hinder the implementation of the program, support the availability of adequate facilities with medicines and other facilities. Bureaucracy is limited because the implementing specialized field of structural deal is not yet available.

2. Despite the achievements did not meet the target of 800 (eight hundred) cows for the Fiscal Year 2015, but when seen from the results 560 (five hundred 
sixty) tail which eventuated in a period of four (4) months showed remarkable success, because it will bring social and economic impact for the community, and will have an impact on government policy in fulfilling the needs / stock of meat, especially the need for the feast.

\section{Suggestion}

1. The successful implementation of the program GBIB already carried out by the City District Government of Kota Waringin Barat should proceed, the local government should support the policies of the central government, to create an advanced form of Perbub policy or legislation as a follow-up of Policy Forms that have been made by the central government.

2. The City District Government of Kota Waringin Barat through the Agriculture and Livestock should improve services to farmers, especially in the implementation of the program implementation unit GBIB there should be special handling in order to avoid overlapping execution of tasks. Power inseminator should be increased in order to reach the waitress to farmers in the district of Kota Waringin Barat can be evenly distributed, not only in certain regions.

\section{References}

1. S. Abdul Wahab, Analysis of Public Policy. Publishing Unit University of Malang. UNM Press Malang (1997)

2. L. Agustino, Fundamentals public Alfabeta Policy (Bandung, 2012)

3. S. Arikunto, Research Procedure a Practice Approach. (Rineka Reserved. Jakarta, 2002)

4. Badjuri, Abdulkahar, Yuwono, Teguh, Public Policy: Concepts and Strategy (Semarang, MPS UNDIP, 2002)

5. Bogdan, Taylor, 1975 in J. Moleong, Lexy. 1989. Metodologi Qualitative Research. Bandung: Remadja work.

6. BPS, Profile of Districts: Figures Kobar in Pangkalan Bun (2014)

7. N.W. Dunn, Introduction to Public Policy Analysis. (Translation) Yogyakarta, GadjahMada University Press (1999)
8. K. Dwiyanto, Agricultural Innovation Development 1 (3): 173-188 (2008)

9. D. Hastuti, S. Nurtini, R. Widiati, Socio-Economic Assessment Implementation Cattle 8. 10. Artificial Insemination in Kebumen. Media Agro 4: 1-12 (2008)

11. T. Herath, A. Anggraeni, L. Praharani, D. Utami, A. Argiris. Informatics Agriculture 21: 81-88 (2012)

12. Howlett, Michael, M. Ramesh, "Studying Public Policy; Policy Cycles and Policy subsystems "Oxford, Oxford University Press (1995)

13. Reports of Agriculture and Livestock Livestock Statistics 2014 Kota waringin Barat.

GBIB Implementation Report 2015, BBPT-HMT Pelaihari, 2015

14. H. Mintzberg, The Manger, s Job. Academy, ed. NY. (1990)

15. L. J. Moleong, Metodologi Qualitative Research. Rosdakarya. Duo (2012)

16 A.R Mustopadidjaja, Policy Process Management, Jakarta, Institute of Public Administration (1984)

17. H. Nawawi, Methods of Social Affairs, Yogyakarta: GadjahMadaPress (1993)

18. M. Nazir, Methods (Jakarta: Ghalia Indonesia, 1988)

19. D. Conscience, Journal Fisip UI (2009)

20. Regulation of 72 of 2012 on Public Service Standard Service Field Agriculture.

21. PRSP. 2011. Final Results Release Livestock Census 2011. Kementan - BPS, Jakarta.

22. W.J.S. Poerwadarminta, The Indonesian General Dictionary (Jakarta: Balai Pustaka, 1985)

23. Quade, S. Steward, Analysis for Public Decisions (New York elsevior Science Publishing Company, 1982)

24. unggono, Bambang, "Based Dynamic wisdom to the Public Policy Analisys. Yogyakarta: Gava Media (1994)

25. Suwitri, Anailisis of Public Policy Implementation. Jakarta: Student Library (2010)

26. H. Sutardjo, Artificial Insemination Service Quality on the DVO Malang. Graduate Program, University of GadjahMada MAP (2003)

27. R. M. Toelihere, Reproduction in Animal Physiology. Space. Bandung.1981b. Artificial insemination in cattle. Bandung: Angkasa (1981)

28. Law of the Republic of Indonesia Number 7 Year 1996 on Food.

29. Winarno, Budi, Theory and Public Policy Process (Yogyakarta, Media Pressindo 2002) 